\title{
An Investigation into the Obstacles to Youth Entrepreneurship in South Africa
}

\author{
Olawale Fatoki (First and corresponding author) \\ Department of Business Management, University of Fort Hare \\ University of Fort Hare, Alice, P.B. X1314, Eastern Cape, 5700, South Africa \\ Tel: 927-40-653-2248Ｅ-mail: ofatoki@ufh.ac.za \\ Lynety Chindoga \\ Department of Business Management, University of Fort Hare \\ University of Fort Hare, Alice, P.B. X1314, Eastern Cape, 5700, South Africa \\ E-mail: leechindoga@gmail.com
}

Received: February 15, 2011 Accepted: February 25, 2011 doi:10.5539/ibr.v4n2p161

\begin{abstract}
Youth entrepreneurial intention is very low in South Africa. The primary objective of this study is to investigate the obstacles to youth entrepreneurial intention. Two sets of questionnaires were self-administered to high school students and university students. The respondents were selected using simple random sampling method. Five-point Likert scale was used to measure the responses. Data analysis includes descriptive statistics, the principal component analysis and T-test. The results indicate that youths perceive lack of capital, lack of skill, lack of support, lack of market opportunities and risk as the main obstacles to entrepreneurial intention. Recommendations to reduce the obstacles to youth entrepreneurship are suggested.
\end{abstract}

Keywords: Youth, Entrepreneurship, Obstacles

\section{Introduction}

The literature has failed to come up with one specific definition which totally describes entrepreneurship. Various definitions have emerged in an attempt to explain entrepreneurship. According to Sathiabama (2010) entrepreneurship is a dynamic process of creating wealth by individuals or groups of individuals. Rwigema and Venter (2004:6) define entrepreneurship as the process of conceptualising, organising, launching and through innovation, nurturing a business opportunity into a potentially high growth venture in a complex and unstable environment. Entrepreneurship is a vehicle to economic growth, success and prosperity. Herrington, Kew and Kew (2009 point out that an entrepreneur is one that shifts economic resources out of an area of low productivity into an area of higher productivity and greater yield. An entrepreneur is one who organises, manages and assumes the risk of a business enterprise

According to Pihie (2009:341) entrepreneurship can be measured in two ways: Actual entrepreneurship (i.e. people that have actually started business) and entrepreneurial intention or latent entrepreneurship (i.e. people that intend to start business). This study focused on latent entrepreneurship. Vesalainen and Pihkala (2000:145) define latent entrepreneurship as a conscious state of mind that directs attention (and therefore experience and action) toward a specific object (goal) or pathway to achieve it (means). Latent entrepreneurs wish to be self-employed in the future and have the possibility to realise self-employment with adequate policy. Pihie (2009:341) notes that intention is the state of mind or attitude which influences entrepreneurial behaviour. A strong association exists between the entrepreneurial intention and the actual behaviour. Henley (2007) points out that entrepreneurship is an intentional activity, in that for many those intentions are formed at least a year in advance of new venture creation. This suggests that there is a link between entrepreneurship and intention.

In South Africa, both latent and actual entrepreneurship is very low compared to international standards. The Total Entrepreneurship Activity (TEA), which is an estimate of the number of working age adults involved in starting or operating businesses up to 3.5 years old, is one of the lowest in the world (Orford, Wood, Fischer, Herrington \& Segal, 2003). TEA is a measure of people in the 18-64 age group who are actively involved in the start-up process or 
those managing a business less than forty two months old. The TEA rate inSouth Africa in 2008 was $7.8 \%$ which is significantly below the average of $13.2 \%$ for the countries that participated in the Global Entrepreneurship Monitor (GEM) annual review (Herrington et al. 2009).

According to Von Broembsen, Wood and Herrington (2005) youths in South Africa are far less likely to start their own businesses compared to those from other countries. The low entrepreneurial activity among youths is one of the primary reasons for the low overall rate of entrepreneurial activity in South Africa. In South Africa, youths are defined as those within the (14-35) age range as mandated by the National Youth Commission Act of 1996 and the National Youth Policy of 2000 (Government Gazette, 2008).

The weak participation of youths in the entrepreneurial process becomes very important in the light of the high rate of youth unemployment in South Africa. Statistics South Africa (2010) notes that South Africa is faced with a very high unemployment rate of $25,2 \%$. Unemployment is highest among the youths especially those in the $15-34$ age bracket. About thirty percent (30\%) of all people in the 15-24 age group, are unemployed and in the 25-34 age group, forty percent $(40 \%)$ are unemployed. Therefore, seventy percent $(70 \%)$ of the unemployed people are youths and of those, forty-seven percent $(47 \%)$ are chronically out of work. This implies that youth unemployment rate is more than twice higher the national average.

Herrington et al. (2009) point out that the growing body of unemployed youths in South Africa places an additional burden on limited government budget that already has a large number of demands on it. Young people's engagement in entrepreneurship helps them to achieve economic independence and reduce their reliance on state welfare. Youth entrepreneurship brings about self esteem and makes the youths more productive members of their families and communities. Youth entrepreneurship brings about growth in an economy in that, by providing employment, the employees and the business would pay taxes thus contributing to government revenue. Entrepreneurship including youth entrepreneurship improves the general standard of society as a whole, which leads to political stability and national security. Youth entrepreneurship reduces crime, poverty and income inequality. This indirectly induces an environment for national and regional economic growth and development (Mutezo 2005: 33).

Thus, an investigation of the possible obstacles to youth entrepreneurship is essential. This study focuses on the youths in the high schools and universities. Kazela (2009) points out the two groups of youths most likely to be involved in entrepreneurship are high school and university graduates. A meta analysis of studies on entrepreneurship in South Africa revealed that no South African study has investigated empirically barriers to youth entrepreneurship with a focus on both university and high school students.

\section{Research objective}

According to Von Broembsen et al. (2005) entrepreneurship is one of the solutions to the high rate of youth unemployment in South Africa. However, youth entrepreneurship is very low in South Africa. The primary objective of this study is to investigate empirically the obstacles to youth entrepreneurship in South Africa.

\section{Literature review}

\subsection{Theoretical construct}

Theories of entrepreneurial intention include Ajzen and Fishbein's 1975 theory of reasoned behaviour, Shapero and Sokol's entrepreneurial event theory of 1982, Bandura's process driven theory of 1991 and Ajzen's theory of planned behaviour of 1991. Ajzen and Fishbein's (1975) theory of reasoned action declare that behaviour is greatly influenced by one's intention to engage in that behaviour and intentions are influenced by attitude towards the behaviour. This implies that intention comes first before the actual behaviour. Another theory of entrepreneurial intention is the process driven theory developed by Bandura in1986. Bandura reasoned that, behaviour is dependent upon an individual's perception that they can carry out the intended action. According to the process driven theory, external environment influences thoughts, which shape attitude and form intention, which if strong enough leads one to action. Shapero and Sokol's (1982) introduced the entrepreneurial event theory. The theory examines life path changes and their impact on individual desirability and perceptions of feasibility related to new venture formation. The underlying assumption of the entrepreneurial event theory is that, critical life changes (displacement) precipitate a change in entrepreneurial intention and subsequent behaviour. Displacement can occur in a negative form such as job loss or a positive form such as financial support. The intention to become an entrepreneur therefore depends on the individual perceptions of desirability and feasibility in relation to that activity.

This study will focus on Ajzen's (1991) theory of planned behaviour. This theory focuses on intentions by an individual which will determine the actual behaviour towards something. According to Ajzen's theory of planned behaviour, there is a relationship between the intention to be an entrepreneur and the act of becoming one. Thus, 
one's intention greatly explains the behaviour. Entrepreneurial intentions are the first step in the evolving and sometimes, long-term process of venture creation. The underlying assumptions of this theory are that:

- Much human behaviour is planned and therefore preceded by intention towards that behaviour.

- Human beings are rational and make systematic use of information available to them when making decisions.

- Intention predicts planned behaviour

\subsection{Empirical review}

Pretorius and Shaw (2004:223) and Atieno (2009:33) report that lack of finance is one of the major constraints to the formation of new enterprises. Entrepreneurs need to access to both internal and external finance to reduce the survive and grow. Maas and Herrington (2006) indicate that lack of financial support is the second major contributor to the low TEA rate in South Africa. Pretorius and Shaw (2004) observe that a large percentage of the failure of entrepreneurial ventures in South Africa is attributed to inadequate capital structure or resource poverty.

According to Lefebvre and Lefebvre (2002:285) and Peterman and Kennedy (2003:131) managerial competency and skills are important for new firm formation. Robertson, Collins, Medeira and Slatter (2003:309) and Bosma, Van Praag, Thurnik and De Wit (2004:227) find that the endowed level of talent of a small business founder is the investment in industry-specific and entrepreneurship-specific human capital which contributes significantly to the performance of new small firm. Herrington and Wood (2003) in the Global Entrepreneurship Monitor Report point out that lack of education and training have reduced management capacity and entrepreneurship in South Africa. The quality and context of the educational system do not promote the development of managerial competencies. This is consistent with the findings of Herrington et al. (2009) that the most crucial factor hindering entrepreneurship in South Africa is lack of education and training. The quality of basic education has deteriorated in South Africa. More than half of the students in high schools in South Africa do not complete their Matric. Lack of basic business skills is a constraint to entrepreneurial intention.

Social and cultural factors can also have an influence on youth latent entrepreneurial intention. Chigunta (2002) finds evidence from developing countries that participation of youths varies with gender and young men are more likely to be self employed than young women. These findings appear to suggest the existence of socio-cultural constraints which tend to affect the participation rate of young women. In addition, most potential entrepreneurs are not aware of government programmes specifically designed to help them. Ndhlovu and Twala (2007) find that access to government financial support is a problem in South Africa. Lack of awareness of the existence of government programmes is another problem faced by youth. Mass and Herrington (2006) agree that most youths are not aware of the various support programmes available and as a result, youths with entrepreneurial tendencies perceive that there is no support from government.

One of the obstacles to the success of an enterprise is lack of willingness to take risk. Fear of failure and embarrassment prevent people with ideas not to explore them and venture into a competitive stage. Many young entrepreneurs become risk averse because of their social environment (Kazela, 2009). In addition, South Africa is characterised by a high crime rate. South Africa ranks in the world's top five countries with the highest murder rates Crime causes stress and additional costs for security and this retards the development of emerging markets such as South Africa. Brown (2001:270) asserts that business is the largest organised group suffering from crime and violence. According to the South African Police Service Crime Statistics (2009) while the incidences of virtually all major categories of crime has fallen during the past year, business related crime is on the increase. Such crimes include burglary at non-residential premises which rose by $6.8 \%$, commercial crimes went up by $4.8 \%$ and shoplifting rose by $1.3 \%$. The actual raw number of robberies at business premises went up by a massive $47.4 \%$ from 6,689 to 9,862 between 2006 an 2008. Most of these robberies were on small business premises. This suggests that the fear of crime can impact on entrepreneurial intention.

Ehlers and Lazenby (2007:108) provide evidence that economic forces can influence market opportunities and ultimately result in prosperity or adversity. on organisations in different industries and in different locations. If youths have negative perception regarding the environment of the business, they might decide not to start their own business. Mollentz (2002) affirm that market issues and demand for products are the most important factors that positively influence new enterprises growth. Thus, bad market conditions and no market opportunities can be a constraint to youth entrepreneurial intention.

\section{Research methodology}

\subsection{Population and sample}

The study focuses on final year University of Fort Hare and Walter Sisulu University students in the Eastern Cape province of South Africa as well as final year students selected from twenty high schools in the the same province. 
The Planning and Development Department at the University of Fort Hare in Alice campus and the Bereau for Institutional Research and Planning at Mthatha campus of Walter Sisulu University, provided statistics of the registered final year students for 2009 for both institutions. According to the statistics obtained, the total final year students for the two universities in 2009 were two thousand and eleven students. For high schools students, the population was obtained from the school principals and clerks. The population of high school students was seven hundred and sixty. The researcher used the probability sampling method for the study. The sample size was determined through the use of Raosoft sample size calculator. Raosoft sample size calculator takes into consideration four factors in determining sample size. These factors include the margin of error, the confidence level, the population and the response distribution. Using Raosoft sample size calculator, the minimum recommended sample sizes for university and high school students were three hundred and three and two hundred and fifty six respectively.

The questionnaire predominantly made use of Five-point Likert scale with 1 meaning strongly disagree to 5 meaning strongly agree to determine the obstacles to youth latent entrepreneurship. Close-ended questions were used for demographic variables. The research instrument was developed taken into consideration other similar studies such as Wong and Choo (2009), Benzing et al. (2009) and Pihie (2009). The questionnaire was pre-tested on a sample of forty respondents from both high schools and universities. The Cronbach's alpha was used as the measure of reliability. The normality of the data was determined by using the Kolmogorov-Smirnov test. The pairwise deletion method was used to treat missing values. The data analysis was done using descriptive statistics, T-test and the principal component analysis. Cooper and Schindler (2003:591) describe principal component analysis as a multivariate statistical method used to describe variability among observed variables in terms of fewer unobserved variables called factors. Principal component analysis could be used to verify a construct of interest. Prinicipal component analysis has two main purposes. Firstly, it is used for data reduction and secondly for detection of structure (underlying dimensions) in a set of variables. Leech, Barrett and Morgan (2005:79) point out that the decision about which factor to retain depends on the percentage of the variance accounted for the variable, the absolute variance accounted for by each factor, and whether the factor can be meaningfully interpreted. Factors with Eigenvalues greater than one are usually retained.

\section{Results and discussions}

\subsection{Response rate and demographics}

The total number of questionnaires distributed to both high school and university students were five hundred and seventy nine and three hundred and fifty seven were returned which represents a response rate of $61.7 \%$. Majority of the respondents for both high school and university students were 24years and below, followed by the 25-29 age range and the 30-34 had the least representation with high school students not having a representation in that range. Female respondents constituted of eighty seven (87) for university students and 69 for high school students. One hundred and nine (109) respondents from university students and ninety two (92) for high school students were male. $69.37 \%$ of the university students' respondents were undergraduates while $30.63 \%$ were post graduate students. Almost uniform representation for all faculties was obtained for university students.

\subsection{Obstacles to youth entrepreneurship}

Table 1 presents the descriptive statistics for obstacles to entrepreneurial intention by university students and high school students.

\section{Insert Tables 1 here}

The results for the university students indicated that lack of savings (4.90), fear of crime (4.89) and lack of collateral (4.75) had the highest means while right partner difficulty (1.02), no one helping (1.79) and no people encouraging (1.93) had the lowest means. For high school students, do not have a good idea (4.96), lack of savings (4.79) and fear of crime (4.51) had the highest means while repaying school loans (1.03), no family member did it (1.06) and right partner difficulty (1.79) had the lowest means. The results indicate that for both university and high school students, lack of capital is a major obstacle to entrepreneurial intention. In addition, both sets of respondents perceive lack of skill, support and market opportunities as obstacles to entrepreneurial intention. High school students tend to have a higher fear of risk than university students.

Tables 2 and 3 present the rotated factor matrix (for university students) and high school students

\section{Insert Tables 2 and 3 here}

For university students, five factors with Eigenvalues greater than one account for $81.68 \%$ of the percentage of variance explained. Factor one was labelled as lack of capital. The Eigenvalue for the factor is 16.76. The factor includes five items. This is the most important factor according to the factor analysis. Cronbach's alpha for the 
factor yielded a value of 0.861 , indicating the reliability of the factor.Factor two was labeled lack of skill. The Eigenvalue for the factor is 9.49. The factor includes six items. Cronbach's alpha for the factor yielded a value of 0.730.Factor three was labelled lack of support. The Eigenvalue for the factor is 6.26 . The factor includes three items. Cronbach's alpha for the factor yielded a value of 0.711 .Factor four was labelled lack of market opportunities. The Eigenvalue for the factor is 4.38. The factor includes two items. Cronbach's alpha for the factor yielded a value of 0.807. Factor five was labelled as risk. The Eigenvalue for the factor is 3.50. The factor includes six items. Cronbach's alpha for the factor yielded a value of 0.820 .

The results for high school students indicate that, five factors with Eigenvalues greater than one account for 87.05\% of the total variance. Factor one was labelled as lack of capital. The Eigenvalue for the factor is 15.223 . The factor includes four items. This is the most important factor according to the factor analysis. Cronbach's alpha for the factor yielded a value of 0.844 , indicating the reliability of the factor. Factor two was labelled lack of skill. The Eigenvalue for the factor is 4.502. The factor includes six items. Cronbach's alpha for the factor yielded a value of 0.812. Factor three was labelled risk. The Eigenvalue for the factor is 2.926 . The factor includes six items. Cronbach's alpha for the factor yielded a value of 0.807 . Factor four was labelled lack of support. The Eigenvalue for the factor is 2.774 . The factor includes two items. Cronbach's alpha for the factor yielded a value of 0.792 . Factor five was labeled lack of market opportunities. The Eigenvalue of the factor is 2.971 . The factor includes two items. Cronbach's alpha for the factor yielded a value of 0.518 .

The T-test was used to investigate if there are significant differences in the mean scores of university students and high school students. The T-test shows an insignificant difference in the mean scores of the two sets of respondents.

\section{Insert Table4 here}

\section{Managerial implications and recommendations}

According to Ajzen's theory of planned behaviour, there is a relationship between the intention to be an entrepreneur and the act of becoming one. The results of this study indicate that there are obstacles to youth entrepreneurial intention in South Africa. This will negatively impact on youth actual entrepreneurship. One of the reasons why South African youths are unwilling to get into entrepreneurship is lack of access to capital, lack of business skills, government support, risk and weak market opportunities.

Entrepreneurship education is one of the initiatives that can be designed to enhance skills and knowledge in entrepreneurship. Entrepreneurial skills include creativity, innovation, risk-taking and ability to interpret successful entrepreneurial role models and identification of opportunities. Entrepreneurial education thus provides basics of such practical business practices. Low levels of financial literacy can influence the degree to which entrepreneurs access formal sources of finance. Entrepreneurship education should be made accessible to all tertiary learners in order to be equipped for business practices. In addition, expert financial training greatly increases the chances of entrepreneurs securing appropriate and affordable finance. To develop further entrepreneurial finance skills and competencies, government can work with organizations such as the South African Banking Association to develop training focusing on finance skills and competencies. In addition, there is the need for more national, regional or specialist support and resources is required to drive up the graduate entrepreneurship rate.

There is an evident skills mismatch between what skills graduate entrepreneurs developed in higher education and what they need in order to survive in the business world. It is recommended that university students and high school students should go for industrial attachments for at least a year during their study to gain valuable business and technical experience. Educational institutions should introduce and strengthen entrepreneurial education. When learners are oriented into entrepreneurship from an early age, it becomes easier to develop successful ventures. There is the necessity for government support initiatives to be efficient. These institutions established by government could take a step in involving the youths by exposing them to their programs, informing them of what they expect from the students in order to receive their full assistance and select a few of them for assistance. Government agencies such as SEDA, Development Corporations can organize practical trainings for students involved in entrepreneurship education or who would like to be involved in entrepreneurial practices. Non-governmental organisations should be well funded through local and international grants to help with the training need of graduate entrepreneurship. Training seminars can also be organized regularly to students involved. Furthermore, a "learning from peers" or mentorship approach can be instituted by government agencies to help students to get involved in entrepreneurship trainings at tertiary institutions. Awareness campaign of government support instruments should be done.

The lack of safety and security in South Africa is causing fear in the development of emerging markets. Government should work in partnership with organisations such as Business against Crime South Africa and Business Unity South Africa to reduce or free the society of crime. The legal system needs to be more efficient so that criminal 
cases against businesses can be dealt with quickly. There is also a need for a well-publicized campaign against crime. More effective policing is needed, including better police visibility, area coverage and faster response times.

The culture of dependency should be reduced through awareness campaign by the government. Youths from historically disadvantaged communities should be informed that social grants will not last forever. Therefore, youths should take entrepreneurship as a career rather than depending on government for grants.

This study recommends that excessive and over complex regulations should be loosened in the case of first time registration for business. This will encourage the youths to register for business. Entrepreneurship awareness day could be organised where individuals will be informed about how to register a business and how much it costs to register a business. Universities and high schools can also be used as sources of information to the students about entrepreneurial opportunities. Entrepreneurship should be encouraged and embedded in education from early formative years through secondary education and be part of the curriculum in all stages of education and all subjects. To achieve this objective, there is the need to teach teachers in entrepreneurial and commercial skills.

\section{Limitations of the study and areas for further research}

The study was mainly based on the perceptions of the youths. A limitation might arise in that possible differences may exist between "perception" and "reality". Another limitation of this study is that it investigated the constraints to youth latent entrepreneurship from students who are in the education system. However, there are some youths who are out of school, who are jobless that would have qualified for this study but were not included. Business culture is lacking in most university graduates hence this should be explored further in a study. Further studies can investigate the barriers faced by actual entrepreneurs (i.e. youths that have actually started their business). This could help to reduce the high failure rate of small entrepreneurial firms in South Africa.

\section{References}

Ajzen, I. (1991). The theory of planned behavior. Organizational Behavior and Human Decision Processes, 50, $179-211$.

Ajzen, I. \& Fishbein, M. (1975). Belief, attitude, intention and behavior. An introduction to theory and research, Boston: Addison Wesley.

Atieno, R. (2009). Linkages, access to finance and the performance of small-scale enterprises in Kenya. Journal of Accounting and Business Research, 3(1), 33-48.

Bandura, A. (1991). Social-cognitive theory of self-regulation. Organizational Behavior and Human Decision Processes, 50, 248-287.

Benzing, C., \& Chu, M. H. (2009). A comparison of motivations of small business owners in Africa. Journal of Small Business and Enterprise Development, 16(1), 60-77.

Bosma, N., Van Praag, M., Thurik, R., \& De Wit, G. (2004). The value of human and social capital investments for the business performance of start-ups. Small Business Economics, 23(1), 227 - 236.

Brown, K.V. (2001). The determinant of crime in South Africa. South Africa Journal of Economics, 69(2), 269-298.

Chigunta, F. (2002). Youth entrepreneurship: Meeting the key policy challenges [Online]. Available: http://www.bg.entrep.ta (04 June 2009).

Cooper, D.R. \& Schindler, P.S. (2003). Business Research Methods. New York: McGraw Hill Inc.

Ehlers, T., \& Lazenby, K. (2007). Strategic management. South Africa concepts and cases. Pretoria: Van Schaik.

Government Gazette. (2008). National youth Policy 2008-2013. [Online]. Available: http://www.pmg.org.za/files (31 July 2009).

Henley, A. (2007). From entrepreneurial aspiration and transition to business start up: evidence from British longitudinal data. Entrepreneurship and Regional Development, 19(3), 253-280.

Herrington, M., \& Wood, E. (2003). Global Entrepreneurship Monitor, South African Report [Online]. Available: http://www.gbs.nct.ac.za/gbswebb/userfiles/gemsouthafrica2000pdf (5 May 2009).

Herrington, M. Kew, J., \& Kew, P. (2009). Tracking entrepreneurship in South Africa: a GEM perspective [Online]. Available: http//www.gemconsortium.org/article (6 September 2010).

Kazela, N. (2009). The Roadmap of Youth Entrepreneurship (MDGs) [Online]. Available: http://www.wcf2009.org/program (20 September 2009). 
Leech, N.L., Barrett, K.C. \& Morgan, G.A. (2005). SPSS for intermediate statistics, use and interpretation. New Jersey: Lawrence Erlbaum Associates Inc.

Lefebvre, E., \& Lefebvre, L. A. (2002). Determinant of export performance and behaviour: A longitudinal study of manufacturing SMEs in Kleinknecht. Econometric Explorations of Survey Data, 5(1), 281-309.

Maas, G., \& Herrington, M. (2006). The Global Entrepreneurship Monitor (GEM) South African Report [Online]. Available: http://budgetspeechcompetition.co.za (29 June 2009).

Mollentz, J. (2002). Creating conducive policy environment for employment creation in SMEs in South Africa [Online]. Available: http://www.unido.org/ (August 23, 2010).

Mutezo, A. T. (2005). Obstacles in the access to SMME finance: an empirical perspective of Tshwane. Unpublished Masters Dissertation, University of South Africa.

Ndhlovu, S., \& Twala, W. D. (2007). Financial needs of small and medium scale contractors in South Africa [Online]. Available: http://www.cib2007.com/papers (September 7, 2009).

Orford, J. Wood, E. Fischer, C. Herrington, M. and Segal, N. 2003. South African executive report [Online]. Available: http://www.gemconsortium.org/articles (July 12, 2010).

Peterman, N. E., \& Kennedy, J. (2003). Enterprise Education: Influencing Students' Perceptions of Entrepreneurship. Entrepreneurship Theory and Practice, 28(2), 129-144.

Pihie, Z. A. L. (2009). Entrepreneurship as a career choice: An analysis of entrepreneurial self efficacy and intention of university students. European Journal of Social Sciences. 9(2), 338-349.

Pretorius, M., \& Shaw, G. (2004). Business plan in bank-decision making when financing new ventures in South Africa. South African Journal of Economics and Management Science 7(2), 221-242.

Robertson, M., Collins, A., Medeira, N., \& Slatter, J. (2003). Barriers to start up and their effect on aspirant entrepreneurs. Education + Training, 5(6), 308-316.

Raosoft. (2009). Sample size calculation. [Online]. Available:http://www.ezsurvey.com/samplesize (June 10, 2009).

Rwigema \& Venter. (2004). Advanced entrepreneurship. Advanced Entrepreneurship. Cape Town: Oxford University Press Southern Africa.

Sathiabama, K. (2010). Rural women empowerment and entrepreneurship development [Online]. Available: http://www.microfinancegateway.org/ga (August 15, 2010].

Shapero, A., \& Sokol, L. (1982). The social dimensions of entrepreneurship. Encyclopaedia of Entrepreneurship, 72-90.

South African Police Service Crime Statistics. (2009). Crime statistics [On line]. Available: http://www.saps.co.za (August 17, 2010).

Statistics South Africa. (2010). Quarterly Labour Force Survey: Quarter 2 (April to June). [On line]. Available: http://www.infor.gov.za/speech (September 17, 2010).

Umsobomvu Youth Fund. (2008). Investing in sustainable livelihoods [Online]. Available: http://www.youthportal.org.za/ur. (July 18, 2009).

Vesalainen, J., \& Pihkala, T. (2000). Entrepreneurial identity, intentions and the effect of the push-factor. International Journal of Entrepreneurship, 3(2), 145-151.

Von Broembsen, M., Wood, E., \& Herrington, M. (2005). Global Entrepreneurship Monitor South Africa report. [Online]. Available:http://www.gsb.uct.ac.za/gsbwebb/userfiles/gem2005.pdf (September 16, 2009).

Wong, M Choo, S. (2009). Entrepreneurial intention: Triggers and barriers to new venture creation in Singapore. Singapore Management Review, 28(2), 47-64. 
Table 1. Obstacles to youth entrepreneurial intention

\begin{tabular}{|c|c|c|c|c|}
\hline \multirow[b]{2}{*}{ Items } & \multicolumn{2}{|c|}{ University } & \multicolumn{2}{|c|}{ High school } \\
\hline & Mean & $\begin{array}{l}\text { Standard } \\
\text { deviation }\end{array}$ & Mean & $\begin{array}{l}\text { Standard } \\
\text { deviation }\end{array}$ \\
\hline Lack of information & 4.61 & 0.936 & 4.14 & 0.911 \\
\hline Lack of skills & 3.41 & 0.904 & 3.79 & 0.987 \\
\hline Difficult bank finance & 4.70 & 0.874 & 4.20 & 0.868 \\
\hline Can't write business plan & 4.23 & 0.923 & 3.89 & 0.888 \\
\hline No family member did it & 2.05 & 0.670 & 1.06 & 0.523 \\
\hline Fear of crime & 4.89 & 0.884 & 4.51 & 0.914 \\
\hline No opportunity in the market & 3.66 & 0.710 & 3.63 & 0.605 \\
\hline Future uncertainty & 2.08 & 0.629 & 3.04 & 0.664 \\
\hline Repaying school loans & 3.83 & 0.836 & 1.03 & 0.552 \\
\hline Right partner difficulty & 1.02 & 0.555 & 1.79 & 0.525 \\
\hline Weak economic environment & 3.44 & 0.634 & 3.36 & 0.603 \\
\hline Lack of funding information & 4.31 & 0.799 & 3.78 & 0.671 \\
\hline Lack of savings & 4.90 & 0.961 & 4.79 & 0.834 \\
\hline Lack of family and friends support & 3.33 & 0.737 & 1.98 & 0.673 \\
\hline Lack of collateral & 4.75 & 0.862 & 3.79 & 0.775 \\
\hline No one helping & 1.79 & 0.639 & 2.03 & 0.625 \\
\hline Lack of business experience & 4.39 & 0.884 & 3.72 & 0.894 \\
\hline Fear of risk & 2.58 & 0.718 & 3.66 & 0.922 \\
\hline No people encouraging & 1.93 & 0.680 & 2.55 & 0.793 \\
\hline No management and entrepreneurial knowledge & 3.57 & 0.816 & 3.68 & 0.980 \\
\hline High registration costs & 3.36 & 0.611 & 3.44 & 0.733 \\
\hline Don't have a good idea & 3.75 & 0.847 & 4.96 & 0.918 \\
\hline Don't have the right contacts & 3.50 & 0.810 & 3.81 & 0.771 \\
\hline Not the right time for me, want to do other things first & 3.89 & 0.648 & 4.20 & 0.982 \\
\hline I am too young & 2.74 & 0.542 & 3.98 & 0.621 \\
\hline Involves too much work and effort & 2.79 & 0533 & 3.44 & 0.658 \\
\hline
\end{tabular}

Table 2. Rotated factor matrix for obstacles (university students)

\begin{tabular}{|c|c|c|c|c|c|}
\hline Factors & $\begin{array}{l}1 \\
\text { Capital }\end{array}$ & $\begin{array}{l}2 \\
\text { Skill }\end{array}$ & $\begin{array}{l}3 \\
\text { Support } \\
\end{array}$ & $\begin{array}{l}4 \\
\text { Market opportunities }\end{array}$ & $\begin{array}{l}5 \\
\text { Risk } \\
\end{array}$ \\
\hline Lack of savings & 0.91 & & & & \\
\hline Lack of collateral & 0.85 & & & & \\
\hline Difficulty in obtaining bank finance & 0.71 & & & & \\
\hline Repaying school loans & 0.64 & & & & \\
\hline High registration costs & 0.52 & & & & \\
\hline Lack of information & & 0.89 & & & \\
\hline Lack of business experience & & 0.82 & & & \\
\hline Can't write business plan & & 0.71 & & & \\
\hline No management and entrepreneurial knowledge & & 0.64 & & & \\
\hline Don't have a good idea & & 0.61 & & & \\
\hline Lack of skills & & 0.57 & & & \\
\hline Lack of funding information & & & 0.79 & & \\
\hline Don't have the right contacts & & & 0.64 & & \\
\hline Lack of family and friends support & & & 0.61 & & \\
\hline No opportunity in the market & & & & 0.64 & \\
\hline Weak economic environment & & & & 0.51 & \\
\hline Fear of crime & & & & & 0.87 \\
\hline Not the right time for me, want to do other things first & & & & & 0.68 \\
\hline Involves too much work and effort & & & & & 0.63 \\
\hline Fear of risk & & & & & 0.59 \\
\hline Future uncertainty & & & & & 0.55 \\
\hline I am too young & & & & & 0.51 \\
\hline Eigenvalue & 16.76 & 9.49 & 6.26 & 4.38 & 3.50 \\
\hline Percentage of variance explained & 41.02 & 15.07 & 12.70 & 8.38 & 4.51 \\
\hline Cronbach's apha & 0.861 & 0.730 & 0.711 & 0.807 & 0.820 \\
\hline
\end{tabular}

Factor loading less than 0.300 have been omitted. 
Table 3. Rotated factor matrix for obstacles (high school students)

\begin{tabular}{|c|c|c|c|c|c|}
\hline Factors & $\begin{array}{l}1 \\
\text { Capital }\end{array}$ & $\begin{array}{l}2 \\
\text { Skill }\end{array}$ & $\begin{array}{l}3 \\
\text { Risk }\end{array}$ & $\begin{array}{l}4 \\
\text { Support }\end{array}$ & $\begin{array}{l}5 \\
\text { Market opportunities }\end{array}$ \\
\hline Lack of savings & 0.98 & & & & \\
\hline Lack of collateral & 0.71 & & & & \\
\hline Difficult bank finance & 0.67 & & & & \\
\hline High registration costs & 0.51 & & & & \\
\hline Don't have a good idea & & 0.81 & & & \\
\hline Can't write business plan & & 0.79 & & & \\
\hline Lack of skills & & 0.76 & & & \\
\hline Lack of business experience & & 0.72 & & & \\
\hline No management and entrepreneurial knowledge & & 0.61 & & & \\
\hline Lack of information & & 0.55 & & & \\
\hline Not the right time for me, want to do other things first & & & 0.78 & & \\
\hline Fear of crime & & & 0.73 & & \\
\hline I am too young & & & 0.69 & & \\
\hline Fear of risk & & & 0.62 & & \\
\hline Involves too much work and effort & & & 0.55 & & \\
\hline Future uncertainty & & & 0.53 & & \\
\hline Don't have the right contacts & & & & 0.72 & \\
\hline Lack of funding information & & & & 0.65 & \\
\hline No opportunity in the market & & & & & 0.74 \\
\hline Weak economic environment & & & & & 0.65 \\
\hline Eigenvalue & 15.223 & 4.502 & 2.926 & 2.774 & 2.971 \\
\hline Percentage of variance explained & 32.23 & 12.81 & 15.06 & 14.91 & 12.04 \\
\hline Cronbach's alpha & 0.844 & 0.812 & 0.807 & 0.792 & 0.518 \\
\hline
\end{tabular}

Factor loading less than 0.300 have been omitted.

Table 4. T-test for the differences in the mean scores of university students and high school students

\begin{tabular}{|l|l|l|l|}
\hline Factor & Scale means for university & Scale means for high school & t-test significance \\
\hline Capital & 4.31 & 4.05 & 0.15 \\
\hline Skill & 3.99 & 4.03 & 0.12 \\
\hline Support & 3.71 & 3.80 & 0.31 \\
\hline Market & 3.55 & 3.50 & 0.42 \\
\hline Risk & 3.16 & 3.81 & 0.11 \\
\hline
\end{tabular}

